\title{
NUCLEAR WASTE MANAGEMENT AND ENVIRONMENTAL MEDIATION: AN EXPLORATORY ANALYSIS
}

M. R. Greene

M. K. Lindell

S. M. Nealey

J. A. Drexler, Jr.

SEPTEMBER 1980

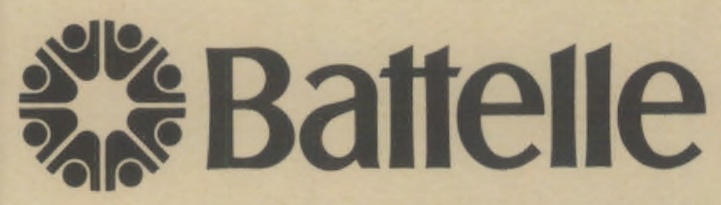

Human Affairs Research Centers

4000 N.E. 41 st Street • Seattle, Washington 98105 


\title{
Legal Notice
}

\begin{abstract}
This report was prepared by Battelle as an account of sponsored research activities. Neither Sponsor nor Battelle nor any person acting on behalf of either: (a) Makes any warranty or representation, express or implied, with respect to the accuracy, completeness, or usefulness of the information contained in this report or that the use of any information, apparatus, process, or composition disclosed in this report may not infringe privately owned rights; or (b) Assumes any liabilities with respect to the use of, or for damages resulting from the use of, any information, apparatus, process, of composition disclosed in this report.
\end{abstract}




\section{Nuclear Waste Management and Environmental}

Mediation: An Exploratory Analysis

Topical Report

September 1980

M. R. Greene

M. K. LindeI 1

S. M. Nealey

J. A. Drexler, Jt.

Prepared for the Waste Management Systems Studies Program of the Pacific Northwest Laboratory of the U.S. Department of Energy

Battelle Memorial Institute Human Affairs Research Centers Social Change Study Center

Energy and Environment Program

Seattle, Washington 98105 
Table of Contents

Page

Introduction ......................... I

Nature of the Waste Management Siting Problem . . . . . . . 1

Brief History of Siting Experiences to Date ......... 3

Current Perspectives on Managing Conflict

over Nuclear Waste................. 6

Environmental Mediation . . . . . . . . . . . . . 10

Definitions .................... . . 10

Experiences to Date . . . . . . . . . . . . 15

Applicability of Mediation to Waste Management Conflict . . 25

The issues ................ . . . 26

The participants .................. . 28

Timing ..................... 30

The mediator ..................... 31

Perceptions of the alternatives............ . 32

Summary . . . . . . . . . . . . . . . . . . 34

References ....................... . . 37 
Nuclear Waste Management and Environmental Mediation:

An Exploratory Analysis

\section{INTRODUCTION}

The purpose of this paper is to explore the possible application of environmental conflict mediation techniques to the siting of a nuclear waste repository. Since much has been written about the issues in nuclear waste management in other contexts (see particularly Bishop, et a1., 1978; Abrams, 1979; Hewlett, 1978; Interagency Review Group, 1979; Schilling \& Nealey, 1979) our focus will be to describe and analyze the major characteristics of a range of techniques that can broadly be called environmental mediation. The uses of these techniques to date and their possible relevance for an issue as complex as nuclear waste management will be discussed. He assume that the reader is not familiar with environmental mediation, but is somewhat knowledgeable about public controversy over nuclear waste management.

\section{Nature of the Waste Management Siting Problem}

The siting of waste repositories is one component of the complex problem of how to dispose of radioactive wastes. There has been no final resolution of this question of how to dispose of the different types of radioactive wastes (high level and transuranic wastes; low level waste and U-mill tailings) that come from different sources such as weapons production, power generation, medical treatment and research activities. In 1978 a Department of Energy task force highlighted the need to develop a national nuclear waste management policy and integrated program (U.S. Department of Energy, 1978). The President then established the 
Interagency Review Group (IRG) to formulate recommendations for "the establishment of an Administrative policy with respect to long-tecm management of nuclear wastes and supporting programs to implement this policy" (IRG, 1979:1). In February of 1980, based on recommendations from this IRG report, President Carter announced a national waste management policy (see discussion under Brief History).

In addition to the technical controversy over the most appropriate disposal method, there are also several public policy controversies. One centers on the role of waste disposal in determining the future development of nuclear power. Some members of the public are concerned that nuclear power should not be developed further unless there are greater assurances that there can be safe storage and disposal of the wastes. Other members of the public believe that the technology currently exists for waste disposal and that there are considerable economic risks in linking reactor licensing (e.g., future power development) and waste disposal issues (IRG, 1979:5). A further public policy issue centers on the question of who bears the cost of a waste repository and who benefits from such a facility. This question has many important considerations of bargaining and compensation, since it is unlikely that a community or region would agree to host a repository without receiving something in turn (Garvey, 1979). These policy issues interact in a political environment that is affected by the various publics' perceptions of the waste management problem (see Bishop, 1978; Lindell, et al., 1978, 1980; Melber, et al., 1978, Rankin and Melber, 1980). It is these larger issues that form the context of any specific siting controversy, and as such are important in defining the conflict to be mediated. 


\section{Brief History of Siting Experiences to Date}

To help put the problems of siting a waste repository in better perspective, we will briefly review several past experiences in siting and developing waste facilities. (A detailed discussion of these central issues can be found in Metlay, 1978; Hewlett, 1978; and Fallows, 1979).

In the beginning, all radioactive wastes were part of the Atomic Energy Commission's (AEC) military program, which had three sites (all of them still active) where high level waste are stored--the Hanford Reservation in Washington State; Savannah River, South Carolina, and the National Reactor Testing Station in Idaho. However, during the $1960^{\prime}$ s and 1970's there was a rapid development of commercial nuclear power. The inventory of fission products from this source steadily grew--to the point that some authors say it is now comparable to the magnitude of the problem posed by the military wastes (Krugmann and Von Hippel, 1977). The growth in the inventory of radioactive wastes was not matched by steady progress in the development of policy for nuclear waste disposal (Hewlett, 1978:10).

During the 1950's and 1960's laboratories and contractors of the AEC did investigate the various technical problems in comercial waste disposal. At that time questions of storage vs. disposal did arise (Hewlett, 1978:9). However, no overall management or policy direction arose to guide the waste disposal effort (Hewlett, 1978:10). Eventually pressure to formulate a coherent policy resulted in AEC analysis of several major issues, including: 1) "how irradiated fuel elements from commercial nuclear pover plants were to be reprocessed and how the resulting wastes were to be prepared for permanent disposal"; 2) "how to 
plan for ultimate disposal of commercial high-level wastes", and 3) "how to dispose of the defense wastes" (Hewlett, 1978:10-13). Policy decisions were made on these three issues by the end of 1970. The AEC decided that:

1) fuel elements from civilian power reactors would be processed by commercial plants and the high-level wastes would be solidified in a form acceptable to $A E C$ for shipnent to a federal repository; 2) AEC would build a federal repository using a bedded salt formation for permanent, irretrievable storage of these wastes (the Lyons site to serve as a demonstration site); and 3) high-level wastes from the defense program at Hanford, Savannah River, and Idaho would be disposed of on site (p. 15).

The first attempt by the AEC to site a waste repository was in Lyons, Kansas. The project was not carried out due to scientific and political objections. Oak Ridge National Laboratories, under contract to the AEC had selected an abandoned salt mine in Lyons for experiments to determine the consequences of exposing bulk salt to radiation and heat. The $\mathrm{AEC}$ then decided that the site would be appropriate for a demonstration repository. Before announcing the plan, the Kansas Nuclear Energy Council gave qualified approval to the AEC, pending further technical and environmental studies (Fallows, 1979). The Kansas Geological Survey, however, took a much more cautious approach, calling for more study. and the Sierra Club supported this approach. Kansas Congressman Joe Skubitz began a campaign to halt the AEC's development of the Lyons site. Most of the local citizens supported the AEC's plans, trusting the government scientists' appraisal, and wanting the new jobs and tax dollars it would bring. The controversy became more heated after the Joint Conmittee on Atomic Energy held hearings on the Lyons proposal. The U.S. Department of Interior presented testimony that agreed with the Kansas Geological Survey. Then the U.S. Senate adopted Kansas Senator Robert Dole's 
amendment to prohibit purchase of the site as a waste repository for at least three years and to set up a Presidential Advisory Commission to study the problem of transporting and storing nuclear wastes (Fallows, 1979). Ultimately the AEC announced that its exploratory tests had revealed unexpected technical problems.

In light of this, a group of officials, including two members of Congress, the Governor, and the Chairman of the Kansas Sierra Club, asked the AEC to remove the state from consideration as a possible location for future waste storage facilities (Fallows, 1979:103).

Though the Lyons site was abandoned, plans for the disposal of high level wastes continued to emphasize placement in salt. Preliminary explorations in Alpena County, Michigan, produced such a local furor that Governor Milliken advised the (then) ERDA that he wanted further exploration in his state terminated. Other states soon had legislation (e.g., Louisiana) or official positions (e.g., Georgia) which expressed a desire to preclude the possibility of siting a waste repository within their jurisdictions (Carter, 1977). Progress was made subsequently toward field work and construction of a demonstration plant, the Waste Isolation Pilot P Lant (WIPP), near Carlsbad, New Mexico. However, currently New Mexico bans the storage or disposal of radioactive waste unless the state concurs with the decision. Nineteen other states have some type of ban on transportation, storage or disposal of radioactive waste. Six other states are considering such legislation.

In February of 1980 the establishment of a comprehensive radioactive waste management program was announced by President Carter. This program is to be consistent "with the broad consensus that... evolved from the efforts of the Interagency Review Group on Radioactive Waste Management [IRG]" (Office of the White House Press Secretary, 1980). Elements of 
the program included: deferring WIPP in New Mexico, mounting an expanded program to investigate potential sites in various geologic media, and developing national plans to establish regional disposal sites for commercial low-level waste. The geologic media to be investigated include basalt and salt beds.

\section{Current Perspectives on Managing Conflict over Nuclear Waste}

Several writers on the public policy questions in the nuclear waste management conflict have emphasized the importance of conflict resolution throughout the process. Garvey (1979) argued strongly, for example, that technical analysis and bureaucratic administration are ultimately not as important in the political resolution of the waste conflict as the "classic" functions of consensus-assessment and interest aggregation. Consensus-assessment identifies the relevant publics--those who have more or less direct interests in the issue--and interest aggregation facilitates the process of bargaining between them (Garvey, 1979). Abrams (1979), who studied the Swedish review of a Nuclear Fuel Safety report, which presented a "safe" method for nuclear waste disposal, argued that this elaborate review process had defined important technical issues that were not clearly seen before. She felt that this at tempt at scientific conflict resolution "has also shown how rapidly scientific and public understanding can be deepened with open and critical reviews, financed by the government, of major projects involving technological uncertainties" (Abrams, 1979:40). Burt (1978), in his discussion of community conflict and nuclear power for the Office of Waste Isolation, presented five principles for resolving such community conflict. They are: avoid situations with high conflict potential; facilitate the 
mobilization of the opposition; pursue a nonpunitive bargaining strategy; focus the bargaining on a few concrete questions; and use third parties to hand le inter-faction antagonism. In a particularly detailed argument Lee (1980a:679) proposed the establishment of a state siting jury to intervene as a third party in the conflict surrounding the siting of a repository, which in his words has become "an unwieldly and controversial task."

To date, there have been several attempts to define more clearly some of the general issues in the waste management conflict and to establish procedures for resolution of some of these issues through activities such as the Interagency Review Group (IRG) and the Keystone Radioactive Waste Management Group. Most recently the State Planning Council has been organized to advise DOE on implementation of the policy of consultation and concurtence with the states. The IRG, as mentioned earlier, was a federal task force appointed by the President to make recommendations concerning national nuclear waste management policy. This task force facilitated communication and interchange among the federal government actors. It also performed a useful function in identifying where people disagreed most vehemently as well as in presenting the range of issues and perspectives for waste management concerns. The Keystone Radioactive Waste Management Discussion Group met in privately sponsored workshop sessions organized by the Keystone Center for Continuing Education. These sessions brought together individuals who have been active in nuclear waste management discussions to define broad issues in the controversy. The members represented a range of policy perspectives. 
In February of 1980, President Carter announced the establishment of the Nation's first comprehensive radioactive waste management program. Consultation and concurrence between the federal government and the states is the primary strategy identified in the President's policy statement. Within this framework, the states will have a continuing role in Federal decision-making on the siting, design and construction of a high level waste repository. Current discussions reflect an attempt to clarify what is meant by these terms and, specifically, what happens if there is nonconcurrence (Smith et al., 1980). In addition to the formal adoption of the policy of consultation and concurrence, the President also announced the establishment of the State Planning Council on Radioactive Waste Management. The Council's functions include (Office of the White House Press Secretary, 1980):

- Recommendation of procedural mechanisms for reviewing nuclear waste management plans and programs in such a way to ensure timely and effective state and local involvement.

- The review of the development of comprehensive nuclear waste management plans including planning activities for transportation, storage and disposal of all categories of nuclear waste.

- Avice on ali aspects of siting facilities for storage and disposal of nuclear wastes.

- Advice on an appropriate role for state and local governments in the licensing process for nuclear waste repositories.

- Advice on proposed federal regulations, standards and criteria related to nuclear waste management programs.

- Identification and recommendation on other matters related to the transportation, storage and disposal of nuclear waste that the Council believes are important.

In addition to the Carter administration's developnent of radioactive waste management policy, of course, is the possibility of Congressional action. A number of legislative proposals have axisen in both the House 
and the Senate over the past few years. During the summer of 1980 one such proposal (S2189) passed the U.S. Senate. While much of the measure was directed to other aspects of radioactive waste management, the Senate bill lays out mechanisms for resolving disputes between state and federal governments in siting repositories for high level wastes, essentially by giving Congress a review role in executive decisions to site a repository. At this writing, no legislation has passed the House, although some floor discussion appears very likely. Therefore, it is not possible to predict changes, if any, in radioactive waste policy that might result Erom legislation in 1980.

In an effort to tie more directly environmental mediation together with the waste management conflict, the mediation organization RESOLVE sponsored a workshop in December, 1979, to develop recomendations to guide future decision-making in this area. Specifically, conference participants were asked to identify possible process alternatives for achieving consensug on the means by which nuclear waste management conflict is addressed. While the first conference did not result in. direct recommendations, it spawned two follow-up meetings that focused more specifically on questions of how to involve citizens more directly in the waste management decision-making process. A number of recombendations regarding public participation emerged.

This brief discussion should illustrate that while many concerned about the various facets of nuclear waste management believe in the use of conflict resolution mechanisms, there is not yet agreement on the most appropriate way to approach this very complex set of problems. This paper has as its purpose an examination of one specific type of conflict 
resolution technique, environmental mediation, for its applicability to resolution of conflict over nuclear waste management. Special attention will be given to its applicability to nuclear waste facility siting.

\section{ENVIRONMENTAL MEDIATION}

Definitions

Conflict resolution is a broad term that encompasses a wide range of techniques including: mediation, arbitration, fact finding, conciliation, negotiation, 1itigation, and citizen participation. Even sheer power, where one side's strength can convincingly settle a conflict in its favor, is a form of conflict resolution. Thus, mediation is but one technique of many that can be used to resolve conflict. In mediation, the disputing parties voluntarily agree to settle their differences through the use of a neutral "third party." Mediation has been a useful tool for conflict resolution in labor/management relations and in some environmental disputes. It is a process whose objective is a solution to a problem that is acceptable to all the parties involved. The advantage of mediation is that it can be less costly (in time and money) than other methods of conflict resolution, such as litigation. Environmental mediation, as a specific technique for conflict resolution, is being examined here because of its success to date in resolving complex, multi-party environmental issues.

A wide range of definitions has been used to date to describe environmental mediation, reflecting a diversity of thinking in the field. One definition, accepted by most practitioners attending a 1978 mediation conference, is the one put forth by Gerald Cormick, an initiator of the concept of environmental mediation, (Baldwin, 1978:2): 
Mediation is a voluntary process in which those involved in a dispute jointly explore and reconcile their differences. The mediator has no authority to impose a settlement. His or her strength lies in the ability to assist the parties in resolving their own differences. The mediated dispute is settled when the parties themselves reach what they consider to be a workable solution.

Cormick believes that two preconditions for successful mediation are a power balance between participants and initiation of the mediation near the impasse point in a controversy (Nice, 1979). Mediators at RESOLVE (a non-profit mediation organization) state that they are promoting "the concept of non-adversarial dispute resolution" (Nice, 1979:4). Another mediator, from the American Arbitration Association, also argues that "in environmental disputes it is utter nonsense to adopt an adversary posture, pitting energy needs against the concern for the environment" (straus, 1978:5). He calls instead for a problem-solving approach to complex disputes. Yet another approach to environmental mediation is that put forward by the Rocky Mountain Center on the Environment (ROMCOE), a Colorado-based mediation group. They describe what they do as "conflict anticipation" (Nice, 1979), and distinguish among:

a) information sharing--providing an arena for all interested parties to come together and exchange their concerns; b) conciliation--employing a range of psychological techniques aimed at correcting misperceptions, reducing hostility and unreasonable fear and clarifying differences; and c) mediation--the process of encouraging parties to a conflict to work together to find a solution agreeable to all parties (Carpenter and Kennedy, 1977).

Despite the rather distinct stylistic differences among techniques that are all called environmental mediation, they do share several common properties. First, the success of any mediation effort depends in part 
upon the ability of the mediators to generate productive communication among the disputants. The emphas is on facilitation is a result of the need for the mediators to induce the disputing parties to accept a common outcome voluntarily. Arbitrators in labor-management disagreements and the courts in litigation have the authority to impose solutions on the disputing parties regardless of how the disputing parties feel about the outcome of the conflict resolution process. The mediator role, on the other hand, does not carry with it the authority to impose solutions and is designed to assist the disputants in arriving at some mutually agreeable solution to whatever problem may be under dispute.

Because of their facilitation skills, the mediators focus their attention more on the process of conflict resolution--the manner in which parties come to some agreement--rather than on the substance of the conflict--the issues in dispute. This process draws upon research and practice in social psychology, law and labor relations. The mediator may provide a forum in which disputing parties can get together to air their differences and create an environment of mutual respect and trust. This can be important when, as is common, disputants have not met to discuss their differences other than in adversarial and highly emotional situations. Also, the mediator can assist by helping disputants explore their own and their adversaries' beliefs about the issue at hand. The mediator helps to insure that all positions are heard and included in whatever solution is reached.

An additional key element in the mediator's role is neutrality. Since the role involves process rather than content, it is critical that 
no disputing party perceive the mediator as invested in or predisposed to any particular outcome from the mediation process.

Several mediators and theorists (Baur, 1977: Straus, 1978; Terra, 1978) point out that environmental mediation differs from mediation of traditional labor-management disputes in several ways. First, in environmental mediation there are more than two parties in the negotiations. Sometimes it is an extremely difficult task to even identify all the legitimate participants to a dispute. Even if those who should participate can be identified, it may still be a problem to gain voluntary participation. Another significant difference is that labor management negotiations are periodic. This makes compromise easier since the parties can always try for a better settlement the next time around. The continuing contractual relationship in labor-management disputes usually assures performance of agreements; such is rarely the case with environmental disputes.

The several styles of environmental mediation can be classified into two types. 1 one is settlement oriented and the other is participation oriented. Settlement-oriented mediation, especially the approach practiced by Cormick (see, e.g., Cormick \& Patton, 1977a) is based upon the assumpion that the disputants do not perceive a need for the mediation unless a balance of power (indicated by the existence of an impasse) becomes obvious. Another reason that the impasse is significant to settlement-oriented mediation is that it comes at a point in the conflict when the relevant parties have made themselves known by their involvement in the early stages of the dispute. Delaying intervention

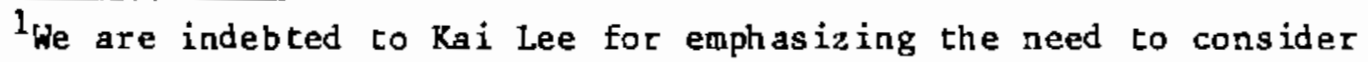
this distinction. 
until impasse is reached also makes it more likely that the issues on which the partiea differ have been articulated. This permits the mediation to address a stable set of issues that define the conflict. Initiating mediation at the point of impasse makes possible a settlement in which all parties feel that they have won something because it is at that point that the participants realize that they all will lose if they do not reach a settlement. Thus the mediation effort is oriented toward an imminent, meaningful deadline, with costs to all parties if no settlement is reached. Another important point about this style of mediation is that it is conducted with outside funding and with official government sanction for the mediator. That is, an independent and neutral body, rather than one of the participants, pays for the mediation effort.

Participation-oriented mediation, more the style of ROMCOE and RESOLVE, raight also be labeled an "open-planning" approach. Citizens are considered to be legitimate critics, early involvement is considered essential to promoting understanding of the issues and, thus, to avoiding an impasse. The focus is more on the education of citizens rather than facilitating representation of all interests in a dispute. The early involvement of the mediator promotes consideration of alternative definitions of the problem. This mediation approach aims at encouraging changes in the individual participants through personal discussions and formation of small groups. In this type of mediation an ultimate settlement is a less salient goal than participation and communication. Typically, the funding source is often one of the participants, usualiy the richest party. This internal funding is not considered to be a 
problem, because the approach is more one of information-sharing and conciliation than one of settlement.

\section{Experiences to Date}

Environmental mediation efforts that have been reported to date illustrate the two approaches described in the previous section. The following discussion presents selected examples of these styles of mediation. Most were chosen for inclusion because their authors described the effort as one of environmental mediation. Several basic characteristics of each case as well as the conditions associated with successful outcomes are described. All the cases share at a minimm two characteristics: some type of environmental isaue is (was) at dispute and a neutral party is (was) used to mediate the conflict. As the cases, well illustrate, there is a wide range of both settlement-oriented and participation-oriented mediation. A variety of disputes have been mediated, including controversial dams, highways, sewage facilities, and industrial plsnts. These disputes have involved an equally wide range of mediators (Iabor negotiators, attorneys, policy analysts, behavioral scientists, planners) and participants (citizens, government officials, environmental groups, and industry representatives). Mediation began at various points in these disputes--sometimes the mediation effort began at the ssme time the conflict arose (participation-oriented), and in other disputes mediation began only after sides had been clearly drawn and an impasse reached (settlement-oriented). The outcomes of these mediation efforts also varied. Some have resulted in successful resolution of the conflict. Other mediation efforts have been considered failures in the sense that a mediated settlement was not achieved. Still others have 
focused attention on the process and encouraged participation in a controversial issue; these participation-oriented mediation efforts have been less concerned with an ultimate settlement.

Table 1 classifies these controversies according to several characteristics: the type of mediation (settlement-oriented or participation-oriented), the issue, the mediators in the process, the participants in the dispute, the point in the process when mediation began and the outcome. Several points can be drawn from these case studies.

First, the controversies that have been successfully resolved by means of settlement-oriented mediation have centered on concrete issues, rather than more abstract concepts. A specific controversial facility (e.g., Snoqualmie River flood Control) or site-specific conflict (e.g., Interstate 90) has been the most common type of issue successfully mediated to date. With such a concrete issue it is more likely that clear positions can be taken, and specific areas of conflict can be delineated. Where a settlement was not reached, the effort was considered a Failure (e.g., West Side Highway). Participation-oriented mediation efforts have dealt more successfully with more abstract conflicts, such as the future direction of a policy (National Coal Policy, Delta County Coal Development). Although these efforts do not usually produce a resolution of an issue, such an outcome is typically not considered a failure.

Both styles of mediation seem more effective when the disputing parties are clearly identifiable, and when all disputing parties are actively involved in the mediation process. If all of the parties are 
TABLE 1. EXPERIENCES IN ENVIRONHENTAL MEDIATION

\begin{tabular}{|c|c|c|c|c|c|c|}
\hline \multirow[b]{2}{*}{ Controveray } & \multicolumn{6}{|c|}{ KEY ELEMENTS } \\
\hline & Issue & Hedpatore & Part1c1pants & $\begin{array}{l}\text { Point In Process } \\
\text { When Hediation } \\
\text { Began }\end{array}$ & Outcone & $\begin{array}{l}\text { Source of } \\
\text { Information }\end{array}$ \\
\hline $\begin{array}{l}\text { Snoqualmie } \\
\text { Rfver Flood } \\
\text { Control, } \\
\text { Hastington }\end{array}$ & $\begin{array}{l}\text { Following aerious } \\
\text { flood In 1959, dam } \\
\text { proposed on Middle } \\
\text { Fork of Snoqualrie. } \\
\text { Resldenta and farmers } \\
\text { supported 1t, environ- } \\
\text { mental1sts opposed. } \\
\text { Reached stalemute. }\end{array}$ & $\begin{array}{l}\text { office of Envicon- } \\
\text { mental Hediation, ow. } \\
\text { Held preliminary dis- } \\
\text { cusalons ulth verlous } \\
\text { parties, then formally } \\
\text { appointed by Governor. }\end{array}$ & $\begin{array}{l}\text { Ten wembera of "core" } \\
\text { group, representing the } \\
\text { range of Interests. } \\
\text { lembers 1dcntified by } \\
\text { mediators. }\end{array}$ & $\begin{array}{l}\text { At Impsese polnt--both } \\
\text { oldeg were effectlve1y } \\
\text { preventing each other } \\
\text { from getting vhat they } \\
\text { wanted. }\end{array}$ & $\begin{array}{l}\text { Agreed to butld a dain- } \\
\text { wth speciflc recom- } \\
\text { mendations, Acceptable } \\
\text { only as total package. } \\
\text { Flood control, re- } \\
\text { creation, vater gupply } \\
\text { dam and coordinated } \\
\text { p1anntng for the } \\
\text { entire basin. }\end{array}$ & $\begin{array}{l}\text { Cormfek and } \\
\text { Patton, 1977a. }\end{array}$ \\
\hline $\begin{array}{l}\text { Interatate } 90 \text {, } \\
\text { Washington }\end{array}$ & $\begin{array}{l}\text { Orig1nal plan to ex- } \\
\text { tend Interstate 90 } \\
\text { into dountom Seattle } \\
\text { 20 years old. Environ- } \\
\text { mental transit- } \\
\text { ortented groups } \\
\text { opposed to so many } \\
\text { auto lanea. Said it } \\
\text { would encourage } \\
\text { spraut on east aide. }\end{array}$ & $\begin{array}{l}\text { Offlce of Envicin- } \\
\text { mental Hediation-- } \\
\text { approached by various } \\
\text { parties to the dlspute. } \\
\text { Governor appointed } \\
\text { the } 2 \text { mediators, after } \\
\text { informal concurrence } \\
\text { of other participante. }\end{array}$ & $\begin{array}{l}\text { Elected officlala from } \\
\text { Cfty of Seattle, } \\
\text { Bellevue, Hercer Ialand, } \\
\text { King County Counc11, } \\
\text { Metro, Department of } \\
\text { Highway, }\end{array}$ & $\begin{array}{l}\text { At impasse foint-- } \\
\text { Dept, of Highways had } \\
\text { tasued new draft FIS, } \\
\text { State Highway } \\
\text { Commission was re- } \\
\text { viewing hearing } \\
\text { recorda. }\end{array}$ & $\begin{array}{l}\text { Agreement in principle. } \\
\text { The memorandum agrec- } \\
\text { ment. was signed by } \\
\text { partictpantg, } \\
\text { witnesged by governor. }\end{array}$ & $\begin{array}{l}\text { Cormick and } \\
\text { Patton, 1977a. }\end{array}$ \\
\hline $\begin{array}{l}\text { Natfonal Coal } \\
\text { Polfey }\end{array}$ & $\begin{array}{l}\text { Need to work out an } \\
\text { agreement between } \\
\text { leading conservation- } \\
\text { lots and coal industry } \\
\text { on how coal can be } \\
\text { exploited 1n ways that } \\
\text { goclety can tolerate. } \\
\text { (Cogl Poldcy Project) }\end{array}$ & $\begin{array}{l}\text { Hot mediation in } \\
\text { strict sense, pre- } \\
\text { mediation to Identify } \\
\text { 1saueg. Concelved by } \\
\text { corporate energy } \\
\text { sanager of Dou } \\
\text { Chemicalmuged Ruleg } \\
\text { of Reagon. }\end{array}$ & $\begin{array}{l}\text { Sixty particlpants-- } \\
\text { half environgentalistg } \\
\text { and half coal indutry. } \\
\text { Divided into five task } \\
\text { forces. }\end{array}$ & $\begin{array}{l}\text { Th1s pre-mediation } \\
\text { project was a geveral } \\
\text { year process. }\end{array}$ & $\begin{array}{l}\text { Mixed reaction, Some } \\
\text { agencies and organi- } \\
\text { zattons feel it vas } \\
\text { not approprtate way to } \\
\text { resolve confliet. } \\
\text { Participants generally } \\
\text { pleaged. }\end{array}$ & Alexander, 1978. \\
\hline
\end{tabular}

$S=$ settlement-orlented mediation

$\mathrm{P}=$ participation-oriented mediation 


\begin{tabular}{|c|c|c|c|c|c|c|}
\hline \multirow[b]{2}{*}{ Controversy } & \multicolumn{6}{|c|}{ KEY ELEAENTS } \\
\hline & Issue & Medlatore & Particlpants & $\begin{array}{l}\text { Point in Process } \\
\text { When Mediation } \\
\text { Began }\end{array}$ & Outcome & $\begin{array}{l}\text { Source of } \\
\text { Information }\end{array}$ \\
\hline $\begin{array}{l}\text { Rare II, } \\
\text { Colorado }\end{array}$ & $\begin{array}{l}\text { Needed agreement about } \\
\text { the areas in the } \\
\text { second Hoadless Ares } \\
\text { levlew and Evaluation } \\
\text { (RARE II)--state's } \\
\text { roadlegs areas on } \\
\text { nat ional forest land. }\end{array}$ & $\begin{array}{l}\text { RESOLvE. (a mediation } \\
\text { organization baged In } \\
\text { Palo Alto). They } \\
\text { were sponsored by } \\
\text { the Forest Service. } \\
\text { Hewlett and Ford } \\
\text { Foundetiong. }\end{array}$ & $\begin{array}{l}\text { Hilderness advocates, } \\
\text { otackmen, skers, } \\
\text { tfrber company. repp, } \\
\text { jeepers, hikers, miners } \\
\text { and environmental1sts }\end{array}$ & $\begin{array}{l}\text { Hiddle. Some felt } \\
\text { batgaining atwuld take } \\
\text { place In Congreas, } \\
\text { others felt it too } \\
\text { late, declsiong al- } \\
\text { ready made. }\end{array}$ & $\begin{array}{l}\text { Agreed on classifica- } \\
\text { tlon for only } 3 \text { of } \\
234 \text { roadless areas. } \\
\text { vieved as learning } \\
\text { process. }\end{array}$ & $\begin{array}{l}\text { Hice, } 1979 \text {. } \\
\text { L1vermore, et al.. } \\
\text { 1978. }\end{array}$ \\
\hline $\begin{array}{l}\text { Power Plant } \\
\text { converston to } \\
\text { cool in New } \\
\text { England }\end{array}$ & $\begin{array}{l}\text { Ongoing evaluation of } \\
\text { ofl to coal convergion } \\
\text { of power plante in } \\
\text { New England--vanted to } \\
\text { determine, by working } \\
\text { wth region's policy } \\
\text { makers as early ag } \\
\text { possible, whether } \\
\text { consengug could be } \\
\text { formed. }\end{array}$ & $\begin{array}{l}\text { The Center for Energy } \\
\text { Polfcy. They were to } \\
\text { gupport deliberations } \\
\text { of Hew England Energy } \\
\text { Policy Council--try } \\
\text { \& build congensug } \\
\text { behind reglonal } \\
\text { energy \& environ- } \\
\text { mental polfcieg. }\end{array}$ & $\begin{array}{l}\text { Qover compantes, } \\
\text { federal \& state regula- } \\
\text { tory agenctes, fuel } \\
\text { auppliers, transporta- } \\
\text { ton industry, } \\
\text { electricity consumers, } \\
\text { communties. FEA } \\
\text { (Federa1 Energy Admini- } \\
\text { otratfon) did not } \\
\text { participate } \\
\text { continuously. }\end{array}$ & $\begin{array}{l}\text { Early. Brought to- } \\
\text { gether all the } \\
\text { Interested parties in } \\
\text { a gerles of meetinga, } \\
\text { Set up act lon planning } \\
\text { group and task forces. }\end{array}$ & $\begin{array}{l}\text { FEA refected what } \\
\text { everyone elee came } \\
\text { to consengur on. }\end{array}$ & Clark, 1977. \\
\hline $\begin{array}{l}\text { De1ta County } \\
\text { Coa } 1 \text { Develop- } \\
\text { ment, Colorado }\end{array}$ & $\begin{array}{l}\text { Potential conflict } \\
\text { currounding futnre } \\
\text { development of under- } \\
\text { groind coal wines in } \\
\text { county. }\end{array}$ & $\begin{array}{l}\text { ROHCOE (Rocky Moun- } \\
\text { tain Center on the } \\
\text { Environment) focal } \\
\text { citizens invited them } \\
\text { to mediate. }\end{array}$ & $\begin{array}{l}11 \text { coal compantea vs. } \\
\text { local c1t1zena (farmers } \\
\text { ranchere, orchardigts) } \\
\text { local government also } \\
\text { involved. }\end{array}$ & $\begin{array}{l}\text { Early, Citizene Uanted } \\
\text { ROMCOE to Identify } \\
\text { areas of conflict } \\
\text { before groups } \\
\text { polarized o posittions } \\
\text { hardened. Worked with } \\
\text { gteering commictee. }\end{array}$ & 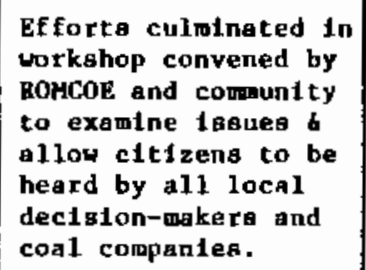 & Baldw1n, 1978 \\
\hline
\end{tabular}




\begin{tabular}{|c|c|c|c|c|c|c|}
\hline \multirow[b]{2}{*}{ Controversy } & \multicolumn{6}{|c|}{ KEY ELEKENTS } \\
\hline & Igsue & Medlators & Participants & $\begin{array}{l}\text { Point in Process } \\
\text { Where Hediation } \\
\text { Began }\end{array}$ & Out come & $\begin{array}{l}\text { Soutce of } \\
\text { Information }\end{array}$ \\
\hline $\begin{array}{l}\text { Bachman's } \\
\text { Warbler, } \\
\text { South Carolina }\end{array}$ & $\begin{array}{l}\text { Dispute over lumbering } \\
\text { In Sauth Carolina'a } \\
\text { Francis Ilarlon } \\
\text { National Foreat, and } \\
\text { home for Hachman's } \\
\text { Harbler. }\end{array}$ & $\begin{array}{l}\text { Natlonal Wildiffe } \\
\text { Pederation attorney } \\
\text { (He vas actually } \\
\text { agked to bring ouit } \\
\text { but he felt situation } \\
\text { amenable to mediation) }\end{array}$ & $\begin{array}{l}\text { Environmentallets } \\
\text { (National Wildlife } \\
\text { Federation) vs. } \\
\text { offictale of U.S. } \\
\text { Forest Service }\end{array}$ & $\begin{array}{l}\text { Hediation began at } \\
\text { point when NWF } \\
\text { considering litigation }\end{array}$ & $\begin{array}{l}\text { Parties agreed to } 6 \\
\text { month moratorium on } \\
\text { all litigation and } \\
\text { timbering, during } \\
\text { uhich mediation panel } \\
\text { heard evidence } \\
\text { arguments. Ultimately } \\
\text { panel's recommendation } \\
\text { adopted. }\end{array}$ & o'Connor, 1978. \\
\hline $\begin{array}{l}\text { PCB Dlacharge } \\
\text { Into Hutson } \\
\text { River, KY }\end{array}$ & $\begin{array}{l}\text { GE Company } \\
\text { discharging PCBs } \\
\text { Into Hudson Kiver }\end{array}$ & $\begin{array}{l}\text { Profeabor Sofaer from } \\
\text { Columbla University } \\
\text { Las School presided } \\
\text { as hearting officer } \\
\text { An guit brought } \\
\text { by WY Environmental } \\
\text { Congervation } \\
\text { Department. }\end{array}$ & $\begin{array}{l}\text { Hew York Environmental } \\
\text { Congervation Depart- } \\
\text { ment and others ve. } \\
\text { GE Company }\end{array}$ & $\begin{array}{l}\text { Regolved in court. } \\
\text { Sofaer took mediator's } \\
\text { role and voluntary } \\
\text { settlement achieved. }\end{array}$ & $\begin{array}{l}\text { Sofaer ruled that GE } \\
\text { Uas liable for } \\
\text { damageo, but recom- } \\
\text { mended mediation } \\
\text { becauge of gertous } \\
\text { oversighte on both } \\
\text { oldeg-State BPA } \\
\text { been excesaively olaw } \\
\text { ln requiring compli- } \\
\text { ance. }\end{array}$ & o'Connor, 1978. \\
\hline $\begin{array}{l}\text { Eau Clair } \\
\text { County, } \\
\text { Wiaconsin }\end{array}$ & $\begin{array}{l}\text { C1ty purchaged and } \\
\text { snnexed town land for } \\
\text { landE111. Needed clay } \\
\text { depositg to line land- } \\
\text { f111. Tow felt } \\
\text { county should operate } \\
\text { landfill that it } \\
\text { should be located } \\
\text { somewhere elae. } 3 \\
\text { other groupo also } \\
\text { opposed facility. }\end{array}$ & $\begin{array}{l}\text { Wisconaln Center for } \\
\text { Publle Pollcy. Brought } \\
\text { Into conflict by } \\
\text { Wiaconeln Public } \\
\text { Intervenor Office. }\end{array}$ & $\begin{array}{l}\text { Wecongin Public } \\
\text { Intervenor, va. the } \\
\text { City, Dept. of Hatural } \\
\text { Reoources of Wiscongin }\end{array}$ & $\begin{array}{l}\text { Public Intervenor'a } \\
\text { office had filed oult } \\
\text { before mediation } \\
\text { begad. }\end{array}$ & 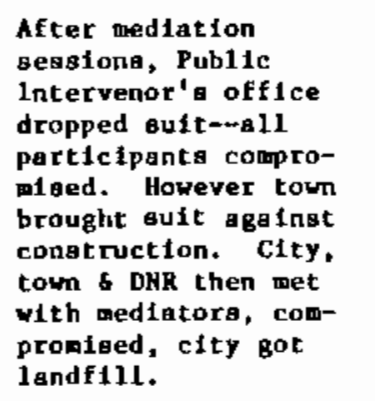 & $\begin{array}{l}\text { Bugterud and } \\
\text { Vaughn, } 1979 .\end{array}$ \\
\hline
\end{tabular}




\begin{tabular}{|c|c|c|c|c|c|c|}
\hline \multirow[b]{2}{*}{ Controverey } & \multicolumn{6}{|c|}{ KEY ELENENTS } \\
\hline & Issue & Mediators & Participants & $\begin{array}{l}\text { Point in Process } \\
\text { Where Mediation } \\
\text { Beggn }\end{array}$ & Outcome & $\begin{array}{l}\text { Sources of } \\
\text { Information }\end{array}$ \\
\hline $\begin{array}{l}\text { Jetty Ialand } \\
\text { Everetc, WA }\end{array}$ & $\begin{array}{l}\text { Port af Everett vanted } \\
\text { to develop Jetty } \\
\text { Ioland for port. Group } \\
\text { of c1tizens had formed } \\
\text { organ1zation called } \\
\text { Jet Set to protect } \\
\text { Lsland from develop- } \\
\text { nent. Ralsed funds } \\
\text { for lavgult. US Fish } \\
\text { \& Wildlife Service } \\
\text { entered diepute in } \\
\text { gupport of Jet Set. }\end{array}$ & $\begin{array}{l}\text { Port commissioner } \\
\text { agked } 2 \text { mediatorg from } \\
\text { UW Office of Environ- } \\
\text { mental Hediation to } \\
\text { informally Inveet Igate } \\
\text { problea. Then formal1y } \\
\text { appointed them. }\end{array}$ & $\begin{array}{l}10 \text { c1tizens concerned } \\
\text { wth probletin. (Brought } \\
\text { together by mediators.) }\end{array}$ & $\begin{array}{l}\text { Almost at Impagae } \\
\text { point--Jet Set Group } \\
\text { ready to file lavsult. }\end{array}$ & $\begin{array}{l}\text { Out of a serieg of } \\
\text { tretings vith } 10 \\
\text { citizeng, positiong } \\
\text { were modified, Bive } \\
\text { and take produced } \\
\text { compromise all parties } \\
\text { wiling to accept. }\end{array}$ & Fibhbein, 1979. \\
\hline $\begin{array}{l}\text { West Side } \\
\text { H1ghway. NY }\end{array}$ & 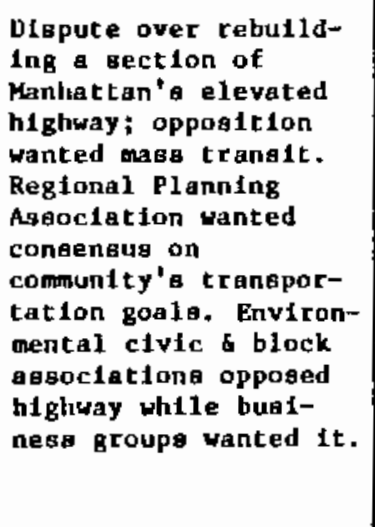 & $\begin{array}{l}\text { Donald Straus, Presi- } \\
\text { dent of Regearch } \\
\text { Institute of American } \\
\text { Arbitration Association } \\
\text { Invited to mediate by } \\
\text { president of Heglonal } \\
\text { Planning Association } \\
\text { and Rep. of Rockefeller } \\
\text { Foundation. }\end{array}$ & $\begin{array}{l}\text { Polfcy ateering } \\
\text { committee-city, atote } \\
\text { reps and local } \\
\text { planning board reps. } \\
\text { Locals h1red own } \\
\text { engineering congul- } \\
\text { tants. (23 organtza- } \\
\text { tlons involved) }\end{array}$ & $\begin{array}{l}\text { Conflict approaching } \\
\text { deadlock when mediator } \\
\text { called in. }\end{array}$ & 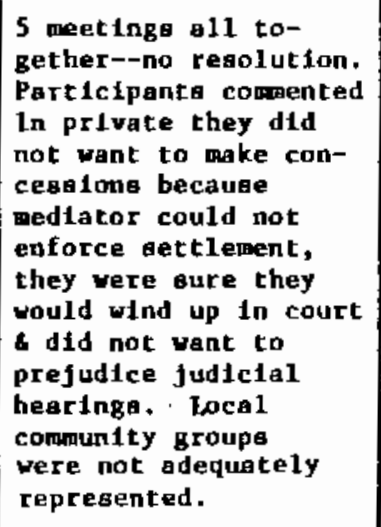 & Lake, 1977. \\
\hline $\begin{array}{l}\text { Rhode Island } \\
\text { Land Use }\end{array}$ & $\begin{array}{l}\text { Conflict over optloal } \\
\text { use of Navy lands that } \\
\text { were to be acquired by } \\
\text { gtate of Fhode Island. }\end{array}$ & 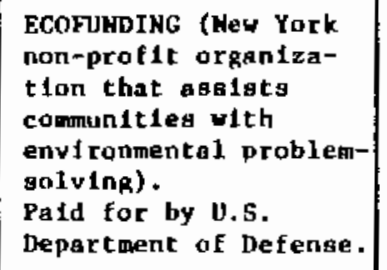 & $\begin{array}{l}30 \text { interest group } \\
\text { leadera--led to the } \\
\text { formation of a } 6 \text { member } \\
\text { Fnecutive Committee } \\
\text { (2 buglness, } 2 \text { labor, } \\
2 \text { envitronmental). }\end{array}$ & $\begin{array}{l}\text { Late. After a } 5 \text { year } \\
\text { Impasae. }\end{array}$ & $\begin{array}{l}\text { The Development of a } \\
\text { set of evaluation } \\
\text { criterla emerged as a } \\
\text { gatifactory oolution. } \\
\text { Consent decree gigned } \\
\text { by oll parties. }\end{array}$ & $\begin{array}{l}\text { Mellfinkoff, } \\
1980 \text {. }\end{array}$ \\
\hline
\end{tabular}




\begin{tabular}{|c|c|c|c|c|c|c|}
\hline \multirow[b]{2}{*}{ Controversy } & \multicolumn{6}{|c|}{ KEY KLEMENTS } \\
\hline & Issue & Mediators & Particlpants & $\begin{array}{l}\text { Point in Proceas } \\
\text { Where Hediation } \\
\text { Began }\end{array}$ & Outcome & $\begin{array}{l}\text { Source of } \\
\text { Information }\end{array}$ \\
\hline $\begin{array}{l}\text { Englewood Metal } \\
\text { Recycling Plant } \\
\text { Colorado } \\
\qquad \text { P }\end{array}$ & $\begin{array}{l}\text { CFsI Corp. recelved } \\
\text { approval for a metal } \\
\text { recycling factlity } \\
\text { from county, but } \\
\text { cft1zen's group } \\
\text { opposed. }\end{array}$ & $\begin{array}{l}\text { RoHCOE (Bocky Mountain } \\
\text { Center on the Environ- } \\
\text { ment) c1cizen ' group } \\
\text { decided to ask for } \\
\text { mediation before } \\
\text { litigarton. }\end{array}$ & $\begin{array}{l}\text { Englewood Cltizen's } \\
\text { group "Consenaus" va. } \\
\text { CFst Corp. }\end{array}$ & $\begin{array}{l}\text { Late in process--right } \\
\text { when citizen's group } \\
\text { congidering litigation }\end{array}$ & $\begin{array}{l}\text { Whole thing fell } \\
\text { through. Although } \\
\text { both gides compromised } \\
\text { positions, one member } \\
\text { of "Consensug" gtarted } \\
\text { lit1gation vithout } \\
\text { conaent of others. }\end{array}$ & Baldwin, 1978. \\
\hline $\begin{array}{l}\text { White F1lnt } \\
\text { Mail, New York } \\
\text { P }\end{array}$ & $\begin{array}{l}\text { Nelghborhood opposed } \\
\text { to shopping mali-- } \\
\text { atcong opposition had } \\
\text { aropped first attempt } \\
\text { at aiting mall. }\end{array}$ & $\begin{array}{l}\text { Planner \& attorney. } \\
\text { Both hired by } \\
\text { developer }\end{array}$ & $\begin{array}{l}\text { Shopplng cenrer } \\
\text { developer ve. civie } \\
\text { a aoclation of } \\
\text { gurrounding nelglibor- } \\
\text { hood. Local gavern- } \\
\text { went also involved. }\end{array}$ & $\begin{array}{l}\text { Parly--advisors } \\
\text { approsched nelghbor- } \\
\text { hood group before } \\
\text { announctng any plan, } \\
\text { to develop mutually } \\
\text { acceptable plan. }\end{array}$ & $\begin{array}{l}\text { Dialog continued } \\
\text { geveral monthe. } \\
\text { Developer agreed to } \\
\text { vhole get of condi- } \\
\text { tons. }\end{array}$ & Baldwin, 1978 . \\
\hline $\begin{array}{l}\text { Grand Laked } \\
\text { Sewage Treat- } \\
\text { ment Plant, } \\
\text { Colorado }\end{array}$ & $\begin{array}{l}\text { Impaage--communfty } \\
\text { pasted bonds for } \\
\text { oewage treatment } \\
\text { factilry but } 5 \\
\text { alternative plnns } \\
\text { developed by engi- } \\
\text { neers falled to } \\
\text { recelve EPA approval. }\end{array}$ & $\begin{array}{l}\text { ROHCOE EPA asked } \\
\text { them to revieb problem } \\
\text { and develop } \\
\text { recommendactons. }\end{array}$ & $\begin{array}{l}\text { local government va. } \\
\text { engineering f1 rm. } \\
\text { EPA aloo involved. }\end{array}$ & At Impasse point. & $\begin{array}{l}\text { ROHCOE vorked with } \\
\text { local government and } \\
\text { engineering firat to } \\
\text { clarify 1saues and } \\
\text { recomend changes in } \\
\text { each of alternative } \\
\text { designg. }\end{array}$ & Balduin, 1978 . \\
\hline $\begin{array}{l}\text { Recntmblnant } \\
\text { UNA, Cambridge, } \\
\text { Mase. }\end{array}$ & $\begin{array}{l}\text { Harvard planned to } \\
\text { bulld a p3 containment } \\
\text { facility o cltizens } \\
\text { worrfed about poten- } \\
\text { tial leake. Some } \\
\text { wanted a ban to auch } \\
\text { research-- Hayor pro- } \\
\text { posed ordinance for } \\
\text { such. Hearings held, }\end{array}$ & 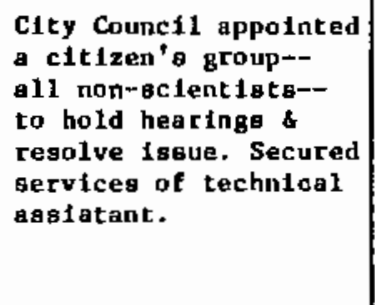 & $\begin{array}{l}\text { Those in support of and } \\
\text { opposed to ban. } \\
\end{array}$ & $\begin{array}{l}\text { At 1mpasse point-- } \\
\text { Afrer learinge held } \\
\text { moratoriug declared } \\
\text { and cltizen'o panel } \\
\text { appointed. }\end{array}$ & $\begin{array}{l}\text { C1ty Council ungni- } \\
\text { mougly adopted } \\
\text { citigen's report. } \\
\text { Added a few extra } \\
\text { requirements to NIH } \\
\text { guidelinea, but eafd } \\
\text { research ghould be } \\
\text { allowed to continue. }\end{array}$ & Yederow, 1977. \\
\hline
\end{tabular}




\begin{tabular}{|c|c|c|c|c|c|c|}
\hline \multirow[b]{2}{*}{ Controversy } & \multicolumn{6}{|c|}{ KEY ELEHENTS } \\
\hline & I asue & Mediators & Part1e1panta & $\begin{array}{l}\text { Point In Process } \\
\text { Where Mediation } \\
\text { Began }\end{array}$ & Outcome & $\begin{array}{l}\text { Source of } \\
\text { Informat 1on }\end{array}$ \\
\hline $\begin{array}{l}\text { Rolilns } \\
\text { Environgental } \\
\text { Services, Inc. } \\
\text { Logan Township, } \\
\text { Neu Jersey } \\
\quad \text { P }\end{array}$ & 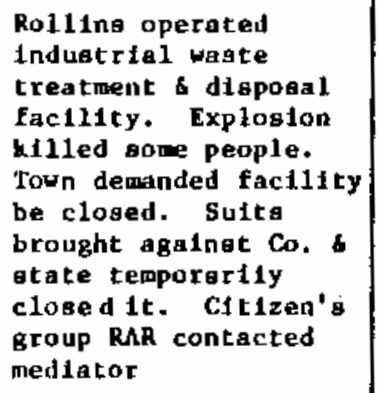 & $\begin{array}{l}\text { Hediator vith office } \\
\text { of Dispute Settlenent } \\
\text { (oDS) In HJ Dept. of } \\
\text { Public Advocate }\end{array}$ & $\begin{array}{l}\text { Citizen'a Group (RAR) } \\
\text { va. Rolling Environ- } \\
\text { mental Servicea, Inc. }\end{array}$ & $\begin{array}{l}\text { Citizens were alao } \\
\text { purauing iftigation } \\
\text { when they contacted } \\
\text { mediator. }\end{array}$ & 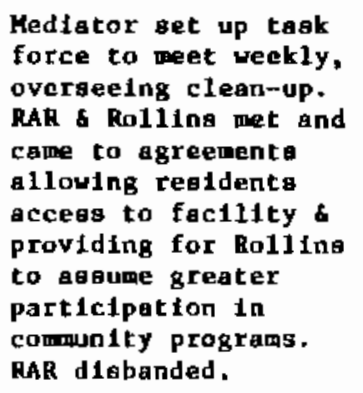 & $\begin{array}{l}\text { Busterud and } \\
\text { Vauglin, } 1979 \text {. }\end{array}$ \\
\hline $\begin{array}{l}\text { Moorlead Malt } \\
\text { Plant, } \\
\text { Horhead, } \\
\text { Mlnnesota }\end{array}$ & $\begin{array}{l}\text { KPIRG filed oult } \\
\text { against Minn. } \\
\text { Environmental Quality } \\
\text { Council becauge EQC } \\
\text { decided an EIs for an } \\
\text { Anheuger-Busch ma1t } \\
\text { plant would not be } \\
\text { required. MPIRG had } \\
\text { not discugeed sult } \\
\text { with A-B or clty. }\end{array}$ & $\begin{array}{l}\text { Environmental Balance } \\
\text { Assoclation (EBA) } \\
\text { (They offered their } \\
\text { Bervices) }\end{array}$ & $\begin{array}{l}\text { MPIRC, Anheuser-Busch, } \\
\text { c1ty of tworhead and } \\
\text { concerned cit1zena. }\end{array}$ & $\begin{array}{l}\text { At Impande-- EBA } \\
\text { inttiated mediation } \\
\text { after aut flled. }\end{array}$ & $\begin{array}{l}\text { HPIRG withdrey Its } \\
\text { adt. Citleeng did } \\
\text { not agree with } \\
\text { wthdraws } 1 \text { and formed } \\
\text { Inform, Inc. }\end{array}$ & Fradjn, 1976. \\
\hline $\begin{array}{l}\text { Foothil1s } \\
\text { Water Treat- } \\
\text { dent Plant, } \\
\text { Denver, Co }\end{array}$ & $\begin{array}{l}\text { A dam to be bullt out- } \\
\text { slde Denver concerned } \\
\text { environmentaliats, } \\
\text { They had filed a lau- } \\
\text { gut but EPA uithdrew } \\
\text { itg objections and the } \\
\text { environmentalists } \\
\text { agreed to negotiate. }\end{array}$ & $\begin{array}{l}\text { Nat lonal widlife } \\
\text { Federition attorney, } \\
\text { Bob Golten }\end{array}$ & $\begin{array}{l}\text { Hational Wild11fe } \\
\text { Federation, Colorado } \\
\text { Open Space Counctl, } \\
\text { Colorado Rlverg Council } \\
\text { vg. EPA }\end{array}$ & $\begin{array}{l}\text { Midway in process. } \\
\text { Environnentalists had } \\
\text { filed lawgult but de-- } \\
\text { cided not very } \\
\text { effective way of } \\
\text { getting the cr concerns } \\
\text { taken care of. }\end{array}$ & $\begin{array}{l}\text { Golten feela they won } \\
\text { 1mportant concessions } \\
\text { in the mediation } \\
\text { procest. }\end{array}$ & HAce, 1979. \\
\hline
\end{tabular}


not identified and involved, disaffected individuals or groups may resort to other means of conflict resolution if they are unhappy with the outcome of mediation. In one classic example, the various sides in a controversy were working toward a mutually agreeable solution to a problem only to find that another individual was caking the problem to the courts for solution (Englewood Metal Recycling Plant).

It is also important for settlement-oriented mediation that the persons involved in the process jointly possess authority to implement settlements and recomended changes. If there is no implementation authority, one or more parties in the dispute may take up their original positions once they are no longer participating in mediation (e.g., the case of power plant conversion to coal in New England). They can then push the controversy to an outcome in which only one side, rather than a11, gains. In this style of mediation it is also important that the parties be willing to change their position on some of the issues in order to avoid returning to an impasse. Failure to achieve active participation--or more importantly, some concessions--from all sides in a dispute may be a result of an incentive for one party to delay the resolution of the conflict or maintain the status quo. In such a case the prospects for a successful settlement-oriented mediation are bleak. There are dimensions other than those appearing in Table 1 that are important in understanding the role of mediation in conflict wanagement. Cormick and Lee (1980), for example, have classified conflict along two dimensions--scope of the dispute and intensity of conflict-and have identified the point at which mediation might be most appropriate. Figure 1 illustrates this classification scheme. Issues of national 


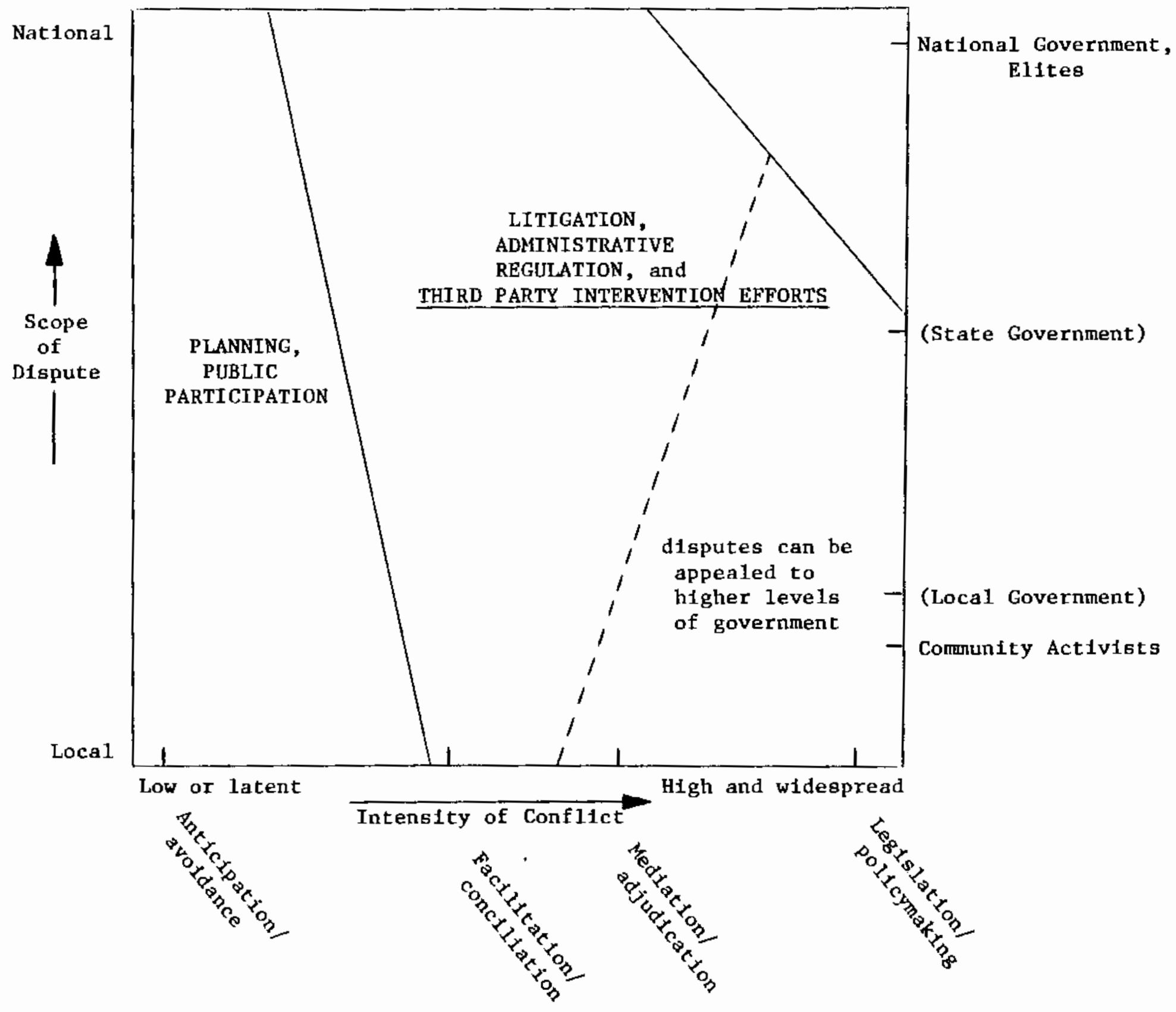

F1gure 1: Appropriate conf11ct resolution mechanisms as a function of scope of dispute and intensity of conflict".

(Adapted from Cormick and Lee, 1980) 
scope and of increasing intensity of conflict have a narrower range where third party intervention might be appropriate than issues that are local in scope. Third party intervention is also not likely to be useful for issues that have a low intensity of conflict, whether local or national in scope. There is, however, a narrow range of issues of national scope where public participation is seen as an adequate resolution technique. It is also important to note that, according to this model, a conflict of high intensity and of national scope should be addressed through a process of national debate involving repregentatives of the federal government and involved nongovernmental groups; one should not expect resolution through third party intervention.

\section{Applicability of Mediation to Waste Management Conflict}

The preceding section has briefly explored several basic characteristics of environmental mediation efforts that have taken place to date. Those characteristics have been discussed in the context of the two styles of mediation. These two styles or problem-solving approaches can be placed on a continum from structuring or organization of the problem (participation-oriented mediation) to decision and implementation of a solution (settlement-oriented mediation). Keeping these two mediation styles in mind, we will now focus the discussion on defining the characteristics or attributes of a specific problem--the siting of a waste repository. These attributes--the issues, the participants, the tining--will be compared to attributes of the environmental mediation efforts discussed in Table 1 . An attempt will also be made to 1 ink the two styles of environmental mediation to the attributes of the problem. 
The issues. Two prerequisites for any type of successful mediation effort are issue identification and prioritization. Siting a waste repository raises a host of issues to be resolved at different decision-making levels and at varioug points in time. Some members of the public and some policymakers tie the waste disposal issues closely to the development of nuclear power; thus to those who define the issue most broadly, the conflict is over the future of nuclear energy. Failure to recognize that some disputants consider the issues to be closely linked could ultimately make any resolution efforts ineffective. Garvey argues for this broader context, saying that waste management program planning "cannot be decoupled from the difficulties currently being experienced within the U.S. nuclear program as a whole" (1979:48). In addition, there are technical questions, as well as political and policy issues, to resolve at a national scale and siting issues to resolve at the regional, state and local levels. These issues must all be very carefully defined and placed on a critical path for resolution. For example, siting issues at a local level cannot be easily resolved before the broader policy and technical questions in waste management are addressed.

The current policy for siting a high level waste repository as announced by President Carter is to identify candidate sites at several locations and in different geologic media. The stages in this process are: national screening, regional characterization, area characterization, location characterization, detailed site characterization, site banking and site selection (Office of the white House Press Secretary, 1980). DOE intends to undertake consultation and concurrence activities in each phase. Thus the potential number of 
specific issues that might need to be resolved in the course of the siting process is quite large. In the early stages of siting a repository (national screening and site characterization) there are both technical and public policy issues that might need resolution. This is in rather marked contrast to most of the emvironmental mediation efforts described in Table 1 . There the issues in dispute, particularly in the settlement-oriented mediation efforts, are much more narrowly defined. They are typified by the construction of a specific facility, such as a dam, or a dispute over a specific practice, such as lumbering in a single forest. In the waste conflict, early stages of siting a repository do not generate such narrowly defined issues. That dispute would include questions of the stability of the chosen geologic medium, the appropriate regulatory procedures in the siting process, and compensation for comminities and states expected to bear the social and economic impacts of a facility for which they receive few direct benefits. Issues of risk associated with radioactivity would likely be of importance here. In summary, the issues in the present stages of siting a waste repository are neither stable, well-defined nor even completely identified. Rather, they are complex, multi-faceted and do not presently have a deadline for resolution. As we have noted previously, participation-oriented mediation might be more useful with such a complex array of issues, since the focus there is less on final disposition of the problem than on encouraging communication and participation in the process.

Community issues defined during the site selection stage or after site selection but before construction are more likely to be sufficiently specific that either style of environmental mediation might be 
appropriate. If those issues are focused on the nature of the hazard (risk associated with radioactivity) the conflict may still not be of a type that lends itself to mediation. Those who feel that nuclear waste is "imnoral" or an inevitable threat to public health may not be willing to compromise. Without a willingness to compromise--to settle for less on one issue in order to get more on another--mediation is not possible.

The participants. A second important characteristic of environmental mediation efforts is the participants. This is a complex issue that includes the need to determine who can, who should, or who will participate. It includes the need to assure a recognition of the power of each of the parties to affect the desired outcomes of the others, to provide an incentive for compromising, and to insure a modicum of respect from all participants for each other. For a waste repository siting controversy the list of potentially affected parties could be quite long. A possible list would include at a minimum local and state government personnel and citizens of candidate sites, state and federal representatives of a host of permit-granting and approving agencies, representatives of the nuclear industry, representatives of environmental and public interest organizations, and other officials from the various levels of government. The very wide range of participants in the waste controversy distinguishes it from most of the mediation efforts reported to date where participation by representatives from three to ten organizations is most comon, and in many cases the participants divide roughly into two or three positions. In the waste conflict, however, the multitude of actors required in the siting process increases the 
complexity of any potential conflict resolution approach and may require that different participants be involved at successive stages of mediation.

One important consideration in encouraging participation in a mediation effort is the assurance to all sides of the controversy that their participation is worthwile. Settlement-oriented mediators feel that there mist be some recognition of a balance of pover among all the parties. Each disputant mut recognize that no one party could reach its objectives without compromising and negotiating with the others; all parties must realize they cannot single-handedly achieve their objectives (Cormick \& Patton, 1977; Nice, 1979).

The existence of a balance of power is a point which generates considerable misunderstanding. This does not mean that all parties have equal resources. It means only that all parties are capable of obstructing the ability of others to achieve their objectives. The power to produce an impasse, in particular, is a source of strength that may be easy to overlook. The National Environmental Policy Act (NEPA) presents opportunities for interested parties to enter the decision process and, consequently, to affect its outcome by challenges to Environmental Inpact Statements.

Another consideration is that all sides aust receive and believe assurances that the mediated solution will be implemented. Cormick, in particular, is skeptical of meetings where traditional foes are invited to come and "reason together" without the incentive of shaping policy (Nice, 1979). Participation-oriented mediators, however, are not seeking an imediate settlement, so recognition of the balance of power (if it even exists) is not as critical. If opposing sides can be convinced to 
carefully consider the positions of others, the participation-oriented mediation can be a success.

A further point brought out by Burt (1978) is that all parties, particularly in a settlement-oriented mediation, also must respect all others in the negotiation and must be willing to accept the fact that all participants hold the power of forcing the negotiations to an impasse. The likelihood of achieving this recognition seems much greater for a narrowly defined issue with only several participants. The early stages of the waste magagement conflict involve many actors who are still trying to clarify the limits of their power to affect the outcome. It may be premature to believe that the participants clearly understand who has enough power to produce an impasse.

Timing. Cormick and Patton (1977) argue that if environmental mediation begins near the point of impasse (settlement-oriented mediation), the affected parties will be visible and highly involved. They feel that "unless the parties have developed and displayed a relative capacity to exercise sanctions, one on the other, they are unlikely to enter good faith bargaining directed toward accommodations of their differences" (1977:9). Others argue that conflict resolution must begin sooner, with the risk that all the parties will not yet have been identified (participation-oriented mediation). Rivkin's (1977) idea of negotiated development (e.g., the thite Flint Mall) must begin early before positions are hardened and there is less room for compromise. Straus and Greenberg (1975) define mediation as up-front dispute settlement and argue that consensus should be sought at four stages of the decision-making process, including clarification of goals, explicit 
notation of the limitations of the data, the choice of analytical methods and the testing of the impact of alternatives.

Participation-oriented mediation, without the goal of a specific settlement, might be more appropriate at the early stages of the siting process to help identify concerns of the various participants. In the later stages of the siting process a stronger orientation toward a settlement to resolve community-specific conflicts might gain vider acceptance.

It is also important to keep in mind that siting a waste repository has a long time frame of implementation. There are no set deadlines that have to be met (another reas on why an exclusive emphas is on settlement-oriented mediation is not likely to work), and the decisions in the program must be staged over long periods of time.

The mediator. This attribute is important in all types of environmental mediation efforts since the choice of a mediator is so important to the ultimate success of the effort. The need for integrity, both in fact and in the perception of the conflicting parties, is emphasized by practitioners (see Baldwin, 1978:20). Total impartiality is also emphasized in establishing credibility with the disputants. The selection of an impartial mediator is related to the funding of any mediation effort. In settlement-oriented mediation it is critical that the mediator be viewed as nonpartisan; therefore funding for his or her effort cannot come from any of the participants. As pointed out earlier, participation-oriented mediation is typically funded by the richest participant. Since a settlement is not the inmediate goal in this style of mediation, such internal funding would not be a problem for mediation 
of nuclear waste issues. This means that DOE could fund a participation-oriented mediation effort to help define and diagnose the issues of dispute more carefully, without affecting its own credibility or that of the mediator. If, at the siting stage, a settlement is desired, it would be very important that the mediator not be considered to be tied to DOE. This probably means that funding should come from an outside source.

An additional point that needs to be brought up here is that environmental mediation as a field is still in its early stages of development. It may be unlikely that a mediator of very high standing would be willing to tackle such a complex dispute. If the mediation effort did not work, there might be negative consequences for further development of the field.

Perceptions of the alternatives. In some environmental mediation efforts (e.g., Englewood Metal Recycling Plant) some participants clearly felt that the dispute was more appropriately settled in court. In other cases, settlement by a legislative body was thought to be more suitable. Participants in the RARE II exercise voiced the concern, "Why should we bargain now? We're going to have to go to Congress, and that's when we're going to do our bargaining." (Nice, 1979). A similar opinion was expressed by the Environmental Policy Center, regarding the Coal Policy Project. Their director announced that "it was presumptuous for the Coal Policy Project to go off to one side to develop a so-called consensus at a time when Congress had already been working for six years on one" (Alexander, 1978). On the other hand, Michael Mcclosky, executive director of the Sierra club, feels that his experience in the coal policy Project persuaded him that: 
the possibilities for resolving policy issues are better in this $k$ ind of setting than they are in public legislative bodies. There's not the same overlay of extraneous issues--the opportunities for public advancement, the competitition for attention. When a topic gets that extra political twist on it, it often gets simplified and horribly mangled. (Al exander, 1978).

An interesting point that emerges in the consideration of the proper forum for conflict resolution is that in the types of environmental mediation cases 1 isted in Table 1 environmentalists seem more skeptical of the process than industrialists (Nice, 1979). Luther Carter, writing about this phenomenon in relation to the Coal Policy Project, said that "clearly, much of the motivation for indutrialists to participate comes from an awareness that industry has been kept on the defensive in the federal and state legislatures and in the courts" (quoted in Nice, 1979). Environmentalists have been winning their battles in the more Eormal political realm, and thus may see less usefulness in informally structured mediation efforts.

This ambiguity concerning the usefulness of the informal, non-governmental environment as a proper place to resolve public policy conflicts has important implications for the waste management program. The early stages of siting a repository have many actors involved at different political levels. These individuals regularly use the political process to resolve their differences. To set up a separate but parallel conflict-resolving mechanism such as settlement-oriented mediation, for a conflict of such high intensity and of such national scope, may be viewed as superfluous by some. Yet others, such as Susskind, argue that political units do not offer appropriate representation to the diffused stake-holders in energy siting controversies, and that "ad hoc representstion around specific concerns 
would ensure that all the relevant gainers and losers vere represented in particular dispute resolution efforts" (1980, p. 4).

Susskind's argument suggests that mediation activities might also be appropriate in the event of a state's nonconcurrence, such as might arise during site banking and site selection. Nonconcurrence could produce an impasse that might be suitable for a settlement-oriented mediation effort. In such a case, the disputants may feel that they have much to lose from an extended deadlock. This would be especially true if the impasse seemed likely to lead to the decision making authority being assumed by another party (e.g., Congress). The disputants might reasonably expect that an authoritative resolution by such an outside party could result in a less satisfactory settlement than they might work out for themselves. In such a case the disputing parties would have exactly the motivation that is present in all successfully mediated conflicts: an awareness that a protracted deadlock could inflict unacceptable costs on both parties.

\section{$\underline{\text { SUMMARY }}$}

This paper has presented a discussion of environmental mediation in the context of the nuclear waste controversy. First, two types of mediation efforts were identified: settlement-oriented mediation and participation-oriented mediation. A range of environmental mediation efforts that have taken place to date were briefly discussed and classified according to the issue being disputed, the mediator, the participants, the point in the conflict at which mediation occurred and the outcome. With in the context of the two identified types of mediation, these characteristics were then discussed for the waste 
management controversy. In the discussion of characteristics of the radioactive waste controversy, the emphasis was placed on the complexity of the issues and the range of participants. Identified differences between the dispute over nuclear waste management and disputes that have been addressed by environmental mediation efforts included: the technical complexity of the waste dispute, the nature of the hazard in the waste dispute (risk from radioactivity), the national scope of the conflict, the high intensity of the conflict, and the long implementation time of the program. Also discussed were the relationship between an environmental mediation effort and alternative mechanisms for conflict resolution, such as NEPA based litigation, consultation and concurrence and state veto or federal preemption.

It was argued that these characteristics make it unlikely--but not inconceivable--that near term use of a settlement-oriented mediation effort could resolve the nuclear waste controversy. Participation-oriented mediation may be a more suitable approach for encouraging constructive communication and reducing conflict among participants in the controversy. Hovever, it has not previously been tested on a controversy of such complexity and such intensity. Well-designed, participation-oriented mediation might prove useful in helping the various parties to the dispute define the issues more carefully.

Several limitations to participation-oriented mediation need to be considered. One is that environmental mediation is such a very new field that it might not be possible to find an experienced mediator willing to attempt such a complex problem. Because so few cases have been reported, 
it is difficult to determine how substantive considerations interact with process concerns in environmental mediation. Thus, the effect of participation-oriented mediation on the nuclear waste conflict is not clear at this point. Still another important queation concerns the compatibility of participation-oriented and settlement-oriented mediation. None of the cases reported to date clearly indicates if an initial focus on participation can be successfully succeeded by an attempt at settlement. More specifically, the factors that would affect the success of such a transition have not yet been determined. 


\section{References}

Abrams, N. E. (1979) "Nuclear Politics in Sweden," Environment, May, pp. 6-11, 38-42.

Alexander, T. (1978) "A Promising Try at Environmental Detente for Coal," Fortune, February 13, pp. 94-102.

American Arbicration Association (1978) "Proceed ings from a One-Day Conference on Environmental Disputes in New York," New York: AAA.

American Association for the Advancement of Science (1977) "Proceedings of Session on Environmental Mediation at 143rd Annual Meeting, 20-25 February."

Baldwia, P. (1978) Environmental Mediation: An Effective Alternative? A report of a Conference held in Reston, Virginia, Jan 11-13. Palo Alto: RESOLVE.

Baur, E. J. (1977) "Mediating Environmental Disputes," Western Sociological Review, Vol. 8, No. 1, p. 16-24.

Bishop, W. P. (1978) "Observations and Impressions on the Nature of Radioactive Waste Management Problems"t in W. P. Bishop, et al., Essays on Issues Relevant to the Regulation of Radioactive Waste Management, NUREG-0412, Washington, D.C.: Office of Nuclear Material Safety and Safeguards, U.S. Nuclear Regulatory Commission, p. 1-19.

Bishop, W. P., et al. (1978) Essays on Issues Relevant to the Regulation of Radioactive Waste Management, NUREG-0412, Washington, D.C.: Office of Nuclear Material Safecy and Safeguards, U.S. Nuclear Regulatory Comisision.

Burt, R. S., et al. (1978) Resolving Conmunity Conflict in the Nuclear Power Issue: A Report and Annotated Bibliography. Prepared for Office of Waste Isolation, Y/OWI/SUB-78/22336.

Busterud, J. \& B. Vaughn (1979) "Mediation or Litigation?" Solid Wastes Management/RRJ, February, pp. 24-31.

Carpenter, S. L. and W. J. D. Kennedy (1977) "Information Sharing and Conciliation: Tools for Environmental Conflict Management," Environmental. Comment, May.

Carter, L. J. (1977) "Nuclear Wastes: Popular Antipathy Narrows Search for Disposal Sites" Science, Vo1. 197, No. 23, September, PP. $1265-1266$.

Clark, P. B. (1977) "Consensus Building: Mediating Energy, Environmental and Economic Conflict," Environmental Comment, May, pp. 9-11. 
Cormick, G. \& K. Lee (1980). "Settling Environmental Disputes." Unpublished proposal, University of Washington.

Cormick, G. \&. K. Patton (1977a) "Environmental Mediation: Defining the Process Through Experience." Paper prepared for AAAS Symposium on Environmental Mediation Case Studies. Denver, Colorado, February.

Cormick, G. W. \& L. K. Patton (1977b) "Environmental Mediation: Potential and Limitations," Environmental Comment, May, pp. 13-16.

Craig, R. (1978) "Proposal for Support of Keystone Radioactive Waste Management Discussion Group Meetings," submitted by the Keystone Center for Continuing Education, October 29.

Fallows, S. (1979) "The Nuclear Waste Disposal Controversy" in D. Nelkin, ed., Controversy: Politics of Technical Decisions, Beverly Hills: Sage Publications.

Federow, H. (1977) Recombinant DNA in Cambridge: Lessons for Nuclear Energy, Oak Ridge, Tenn: Oak Ridge Associated Universities, Institute for Energy Analysis. Occasional Paper. September. ORAU/IEA (0)-77-25.

Fishbein, G. (1979) "The Case for Mediating Environmental Disputes," Washington Post, 3-10, P. A-13.

Fradin, D. M. (1976) "The Moorhead Malt Plant Dispute: Report of Minnesota's First Environmental Mediation," St. Paul: Environmental Balance Association of Minnesota.

Frech, G. (1978) "Simulation Gaming Applied to Controversial Facility Planning: Experimental Results," Journal of Environmental Systems, Vol. 8, No. 2, Pp. 179-193.

Garvey, G. (1979) "WWTS Policy and Public Choice," for Office of Nuclear Waste Isolation (ONWI), Report 非WI/SUB/78/E512-0I200-1, January.

Gladwin, T. (1978) "Environmental Conflict," EIA Review, 161:2 October, Pp. $48-49$.

Goodin, R. E. (1978) "Uncertainty as an Excuse for Cheating Our Children: The Case of Nuclear Wastes," Policy Sciences, Vo1. 10, Pp. 25-43.

Hewlett, R. G. (1978) "Federal Policy for the Disposal of Highly Radioactive Wastes from Cormercial Nuclear Power Plants: An Historical Analysis" Washington, D.C.: Executive Secretariat, U.S. Department of Energy, March.

Interagency Review Group (1979) "Report to the President by the Interagency Review Group on Nuclear Waste Management, "Washington, D.C.: IRG, March. 
Kantrowitz, A. (1977) "The science court experiment: Criticisms and responses," Bulletin of Atomic Scientists, April, pp. 43-ff.

Kerr, R. A. (1979) "Geologic Disposal of Kuclear Wastes: Salt's Lead is Chal lenged," Science, Vol. 204, No. 11, May, p. 603-306.

Krugmann, H. \& F. von Hippel (1977) "Radioactive Wastes: A Comparison of U.S. Military and Civilian Inventories" Science, Vol. 197, No. 26, August, pp. 883-885.

Lake, L. M. (1977) "Mediating Environmental Disputes" Ekistics, Vol. 44, No. 262, September, pp. 164-170.

Lee, K. (1980) "Federalist Strategy for Nuclear Waste Management," Science, Vol. 208, May, pp. 679-684.

Lindell, M. K., et al. (1978) Radioactive Wastes: Public Attitudes Toward Disposal Facilities, BHARC-411-004, Seattle: Battelle Human Affairs Research Centers.

Lindell, M. K., et al. (1980) Social Issues and Energy Alternatives: The Context of Conflict Over Nuclear Power, BHARC-411-003, Seattle: Battelle Human Affairs Research Centers.

Livermore, D., et a1. (1978) "RARE II Methodology Report," Palo Alto: RESOLVE.

Marshal1, E. (1978) "Environmental Groups Lose Friends in Effort to Control DNA Research," Science, Vol. 202, December 22, pp. 1265-1269.

McCarthy, J. (1976) "Resolving environmental conflicts," Environmental Science and Technology, January, pp. 40-43.

McClosky, M. (1977) "Environmental Conflicts, Why Aren't Hore Negotiated." Presented at Aspen Institute, Aspen, Colorado, July 8.

Melber, B. D., et al. (1977) Muclear Power and the Public: Analyg is of Collected Survey Research, PNL-2430, Seattle: Battelle Human Affairs Research Centers for Savannah River Operations office of U.S. DOE, November.

Metlay, D. S. (1978) "Observations and Impressions on the Nature of Radioactive Waste Management Problems" in W. P. Bishop, et al., Essays on Issues Relevant to the Regulation of Radioactive Waste Management, NUREG-0412, Washington: Office of Nuclear Material Safety and Safeguards, U.S. Nuclear Regulatory Commission, p. 51-59.

Metz, W. D. (1978) "New Review of Nuclear Waste Disposal Calls for Early Test in New Mexico," Science, Vol. 199, No. 31, March, pp. 1422-1423.

Mellinkoff, D. (1980) "Mediation Settles Rhode Island Land Use Dispute," Environmental Consensus, Spring, pp. 3-5. 
Murphy, E. (1977) "Environmental Bureaucracies Appraised," Ekistics, Vol. 262, September, pp. 157-170.

Nelkin, D. (1978) "Participation and Expertise in Nuclear Decisions: Some European Experiments," EIA Review, Vol. 2, October, pp. 42-44.

Nice, J. (1979) "Stalemates spawn new breed: The eco-mediators," High Country News, Vol. 11, No. 6, Friday, March 23, p. 1 .

O'Connor, D. (1978) "Environmental Mediation: The State-of-the-Art," EIA Review, Vol. 2, October, Pp. 9-17.

Piper, T. (1978) "Using the Broadcast Media to Help Resolve Environmental Disputes," EIA Review, Vol. 2, October, p. 46.

Reiser, R., H. Schilling, R. Smith \& J. Mountain, eds., (1980)

"Consultation and Concurrence," ONWI-87, Workshop proceedings of the Orcas Meeting, Eastsound, Washington, September 23-26, 1979.

Rivkin, M. D. (1977) "Negotiated Development: A Breakthrough in Enviornmental Controversies," Environmental Comment, May, pp. 3-ff.

Rohrbaugh, J. \& P. Wehr (1978) "Judgement Analysis in Policy Formation: A New Method for Improving Public Participation," Public Opinion Quarterly, Vol. 42, No. 4, Winter, Pp. 521-532.

Schein, E. (1969) Process Consultation. Reading, Mass: Addison-Wesley.

Schilling, A. H. \& S. M. Nealey (1979) Public Participation in Nuclear Waste Management, BHARC-411-021, Seattle: Battelle Human Affairs Research Centers.

Smith, R. F. (1979) Participant at Keystone Public Participation Workshop, June 17-20, Personal communication with authors.

Smith, R. F., F. A. Morris \& A. H. Schilling (1980) "State of the Art Paper on Consultation and Concurrence," Draft, Battelle Human Affairs Research Centers, May.

Straus, D. B. (1978) "Mediating Environmental Disputes," Arbitration Journal, Vol. 33 , No. 4 , PP. 5-8.

Straus, D. B. (1977) "Mediating Environmental, Energy, and Economic Trade-offs," Arbitration Journal, Vol. 32, June, Pp. 96-110.

Straus, D. \& M. Greenberg (1975) "Data Mediation of Environmental Disputes: Converting Facts from Weapons into Tools," Summary of remarks made at 14lst annual meeting of AAAS and Society for General Systeme Research, January 30, New York: American Arbitration Association.

Surrey, T. \& C. Huggett (1976) "Opposition to Nuclear Power: A Review of International Experience," Energy Policy, Vol. 4, No. 4, pp. 286-307. 
Susskind, L. E. "Resolving environmental disputes through adhocracy," Environmental Consensus, 1980 , pP. 3-5.

Terra, S. (1978) "John Busterud: It's Better to Mediate," EPRI Journal, Vol. 3, No. 10, December, PP. 23-25.

U.S. Department of Energy, Directorate of Energy Research (1978) Report of Task Force for Review of Nuclear Waste Management. Draft. Washington, D.C., February.

White House Press Secretary, The Office of, (1980) Executive Order, The State Planning Council on Radiosctive Waste Management, February 12, 1980. 
No. of

Coptes

W. Ballard Jr.

Offlce of Energy Programs

Department of Energy

Washington, D.C. 20545

D. L. Bodde

Offlce of Nuclear Pollcy

Energy Research

Department of Energy

Washington, D.C. 20585

A. A. Chura

Ch1cago Patent Group

Department of Energy

9880 South Cass Avenue

Argonne, IL 60439

T. Cotton

Office of Technology

Assessment

Washington, D.C. 20510

27 DOE Technical Information Center

P.0. Box 62

Oak Ridge, TN 38730

C. H. George

Office of Waste Isolation

Department of Energy

Washington, D.C. 20545

T. Greenwood

Department of Political Sclence

Massachusetts Institute of Technology

Cambridge, MA 03139

G. Graves

Los Alamos Sclentific

Laboratory

Los Alamos, NM 87544

C. A. Heath

Office of Waste Isolation

Department of Energy

Washington, D.C. 20545
No. of

Copies

T. C. Hobson

Office of Consumer Affairs

Department of Energy

Washington, D.C. 20545

D. Jenkins

Office of Public Affalrs

Department of Energy

Washington, D.C. 20545

B. E. Jordan

Office of Waste Operations and Technology

Department of Energy

Washington, D.C. 20545

E. F. Mastal

Offlce of Resource Management and Planning

Department of Energy

Wash1ngton, D.C. 20545

S. Meyers

Office of the Deputy Assistant Secretary for Nuclear Waste Management

Department of Energy

Washington, D.C. 20545

G. Oerte1

Office of Warte Operations and Technology

Department of Energy

Washington, D.C. 20545

A. F. Perge

Office of the Deputy Assistant Secretary for Nuclear Waste Management

Department of Energy

Washington, D.C. 20545

J. Pomeroy

National Academy of Sclences

Washington, D.C. 20418

D. Rosenbaum

Department of Radlation Protection

Environmental Protection Agency

Washington, D.C. 20460 
No. of

Coples

J. W. Rowen

Offlce of Resource Management and Planning

Department of Energy

Washington, D.C. 20545

L. J. SmIth

TRU Waste Systems Office

Rocky Flats Plant

Golden, CO 80401

S. L. Topp

Savannah Rtver Laboratory

Atken, SC 29801

V. G. Trice

Office of Resource Management and Planning

Department of Energy

Washington, D.C. 20545

E. J. Wahlquist

Offlce of Resource Management and Planning

Department of Energy

Wash1ngton, D.C. 20545

Richland Operations office

3 Contracting office

P. A. Cralg

O. J. Elgert

H. E. Ransom

J. J. Schreiber

M. W. Shupe

Offlce of Nuclear Waste Isolation

N. Carter

J. Finley

M. Kehnemuy1

B. Rawles

J. Mountain
No. of

Copies

Pac1f1c Northwest Laboratory

5 Technical Files

2 Publishing Coordination

D. E. Olesen

J. B. Burnham

T. L. Chikalla

D. E. Deonigi

R. P. Marsha11

M. R. Kreiter

J. V. Robinson 